\title{
SOMATIC SEEDS OF PLANTAGO ASIATICA L.
}

\author{
JoANNA MAKOWCZYŃSKA, EMILIA ANDRZEJEWSKA-GOLEC \\ Department of Biology and Pharmaceutical Botany \\ Medical University of Łódź \\ Muszyńskiego 1, 90-151 Łódź, Poland \\ e-mail: e.andrzejewska@wp.pl
}

(Received: September 22, 2005. Accepted: December 16, 2005)

\begin{abstract}
Somatic seeds of Plantago asiatica L. were produced for the first time. Shoot-tips isolated from in vitro obtained 4-week shoots were encapsulated using sodium alginate and calcium chloride. Capsules with or without sucrose and with and without cytokinin - indole-3-butyric acid (IBA) were used. Sucrose presence in capsules very distinctly influences somatic seeds of Plantago asiatica germination and their conversion into plants. However, addition of IBA to capsules has not clear influence on the ability of plant regrowth. Plantlets transplanted to soil grew to phenotypically normal plants.
\end{abstract}

KEY WORDS: Plantago asiatica, encapsulation, cold storage, conversion into plants.

\section{INTRODUCTION}

Asiatic plantain - Plantago asiatica L. (Plantaginaceae) is a common and valuable medicinal Far East plant (Andrzejewska-Golec and Makowczyńska 2005). In vitro culture of Asiatic plantain was initiated in 1996 by Tu. At present this species has been cultured in vitro in the Department of Biology and Pharmaceutical Botany, Medical University of Lodz (Andrzejewska-Golec and Makowczyńska 2001; Makowczyńska and Andrzejewska-Golec 2000, 2003, 2004a, b; Makowczyńska et al. 2005).

The aim of this work was to produce somatic (artificial, synthetic) seeds of Plantago asiatica and study their germination and conversion into plants. Preliminary experiments with somatic seeds of this taxon were presented in the Biotechnological Section of Pharmaceutical Symposium (Makowczyńska and Andrzejewska-Golec 2004a). There are no reports on somatic seeds production of any Plantaginaceae taxon.

\section{MATERIAL AND METHODS}

\section{Plant material}

The 4 or 6-week shoots were obtained in vitro from 4week seedlings. The seeds for in vitro culture were received from the Botanical Gardens, Faculty of Science, University of Tokyo. The shoot tips $(\mathrm{ca} 0.5 \mathrm{~cm})$ from these shoots were explants to produce somatic seeds.

\section{Culture conditions}

All cultures were conducted in growing chamber, $25 \pm 2^{\circ} \mathrm{C}$, 80-90\% humidity, light intensity $40 \mu \mathrm{M} \times \mathrm{m}^{-2} \times \mathrm{s}^{-1}$.

\section{Encapsulation of shoot tips}

The explants were encapsulated in Murashige and Skoog medium (MS), supplemented with 3 or 3.5\% sodium alginate (Sigma) solution with 3 or $3.5 \%$ sucrose or without it, and with or without cytokinin IBA. Alginate droplets, each containing one shoot tip, were placed into calcium chloride solution.

Eight variants of capsules were produced (see Fig. 1). The alginate beads about $5 \mathrm{~mm}$ in diameter, were then collected to sterile filter paper in Petri dishes sealed up with Parafilm.

\section{Storage experiments}

The obtained (as above described) somatic seeds were stored in the refrigerator at $4-8^{\circ} \mathrm{C}$ for 42 days and for three variants of capsules: $3 \%$ alginate; $3.5 \%$ alginate; $3.5 \%$ alginate and 1.5 saccharose - also for 56 days.

\section{Germination and conversion into plants}

After the storage period the beads were cultured for plants recovery on MS medium in Petri dishes and incubated as described above. After each week of culture the following data were recorded:

1) frequency of the shoot formation,

2) rooting frequency,

3) morphological data (shoot length, number of leaves). 


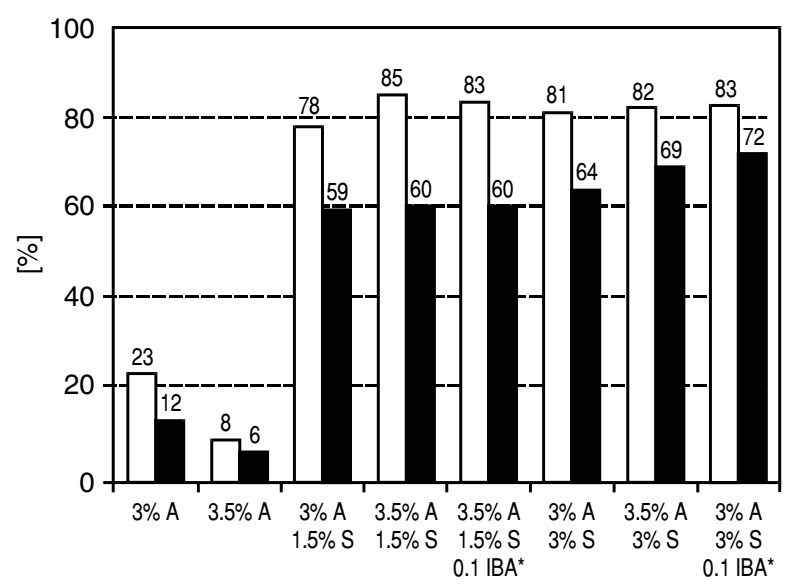

Composition of capsule

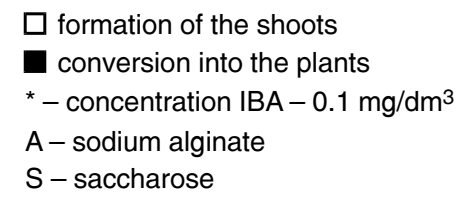

Fig. 1. The ability of somatic seeds of Plantago asiatica L. to form shoots and to convert into the plants, 6-week culture.

Plantlets having well developed roots were transferred into pots with a sterilised mixture of soil, sand and peat. Plantlets were covered with glasses to maintain high humidity. The glasses were opened after seven days.

\section{RESULTS}

In this work, encapsulated shoot tips of Plantago asiati$c a$ were obtained (Fig. 2). In preliminary study (Makowczyńska and Andrzejewska-Golec 2004a) artificial seeds were placed on three types of agar-basal media: MS, Schenk and Hildebrandt medium, Lloyd and McCown medium for germination, i.e. emergence of shoots and roots. For the present study only MS medium was used because it was found to be the best.
Somatic seeds germination and their conversion into plants are presented in Figs 3-6.

The ability of somatic seeds to form shoots and to convert into plants in the 6-week culture on MS medium after 6 -week storage in refrigerator is presented in Figure 1. In the case of capsules without sucrose, the percentage of shoots formation and their conversion into plants was low.

The morphology of plants from the 6-week culture is presented in Table 1. The plants obtained from somatic seeds with sucrose capsules were higher and contained more leaves in comparison with plants from somatic seeds without sucrose in capsules.

Continuation of capsules preservation in low temperature (to 8 weeks) caused a decrease in germination capacity about $32 \%$, conversion into plant about $18 \%$ for version of capsules with $3.5 \%$ alginate and $1.5 \%$ saccharose. The artificial seeds without sucrose transferred on MS medium were dying out.

The plants obtained from Plantago asiatica synthetic seeds were phenotypically normal (Fig. 6).

\section{DISCUSSION}

The Murashige conception of artificial seeds for germplasm storage derived from the year 1977 (Redenbaugh et al. 1991). The first somatic seeds were encapsulated somatic embryos (Redenbaugh et al. 1987, 1991). However, we failed to produce $P$. asiatica somatic embryos of adequate quality (Makowczyńska and Andrzejewska-Golec 2000).

The encapsulation of non-embryogenic in vitro-derived vegetative micropropagules for germplasm storage has been explored in some plant species (Bach 2001; Mathur et al. 1989; Pattnaik and Chand 2000; Paul et al. 2000; Rout et al. 2001). These micropropagules might be shoot tips or axillary buds (Danso and Ford-Lloyd 2003; Ganapathi et al. 1992; Mathur et al. 1989; Pattnaik and Chand 2000; Paul et al. 2000). The encapsulation of in vitro derived shoot tips to develop somatic seeds has been employed as a suitable alternative to the use of somatic embryos, for example: shoot tips of Musa paradisiaca cv. Basrai (Gana-

TABLE 1. Morphology of plants regenerated from somatic seeds of Plantago asiatica L. after 6-week culture on MS medium.

\begin{tabular}{|c|c|c|c|c|}
\hline $\begin{array}{l}\text { Composition } \\
\text { of capsule }\end{array}$ & $\begin{array}{c}\text { Mean number } \\
\text { of leaves }\end{array}$ & $\begin{array}{l}\text { Mean length of shoots } \\
\qquad[\mathrm{cm}]\end{array}$ & $\begin{array}{l}\text { Mean number } \\
\text { of roots }\end{array}$ & $\begin{array}{l}\text { Mean length of roots } \\
{[[\mathrm{cm}]}\end{array}$ \\
\hline $3 \% \mathrm{~A}$ & $4.38 \pm 0.47$ & $1.85 \pm 0.24$ & $1.43 \pm 0.30$ & $1.69 \pm 0.36$ \\
\hline $3.5 \% \mathrm{~A}$ & $4.57 \pm 0.65$ & $2.07 \pm 0.13$ & $1.80 \pm 0.13$ & $3.40 \pm 0.55$ \\
\hline $3 \%$ A $1.5 \% \mathrm{~S}$ & $4.86 \pm 0.21$ & $2.74 \pm 0.13$ & $1.88 \pm 0.13$ & $3.69 \pm 0.15$ \\
\hline $3.5 \%$ A $1.5 \% \mathrm{~S}$ & $5.44 \pm 0.39$ & $2.93 \pm 0.18$ & $1.67 \pm 0.21$ & $3.10 \pm 0.25$ \\
\hline $\begin{array}{l}3.5 \% \text { A } 1.5 \% \text { S } \\
0.1 \mathrm{mg} / \mathrm{dm}^{3} \mathrm{IBA}\end{array}$ & $5.33 \pm 0.20$ & $2.94 \pm 0.13$ & $1.69 \pm 0.10$ & $3.73 \pm 0.13$ \\
\hline $3 \%$ A $3 \% \mathrm{~S}$ & $5.90 \pm 0.26$ & $2.81 \pm 0.17$ & $1.88 \pm 0.15$ & $3.78 \pm 0.19$ \\
\hline $\begin{array}{l}3 \% \text { A } 3 \% \mathrm{~S} \\
0.1 \mathrm{mg} / \mathrm{dm}^{3} \text { IBA }\end{array}$ & $5.81 \pm 0.18$ & $3.59 \pm 0.15$ & $1.83 \pm 0.13$ & $4.13 \pm 0.15$ \\
\hline
\end{tabular}

Values are the mean \pm standard error of 27-30 somatic seeds per each treatment (composition of capsule). 

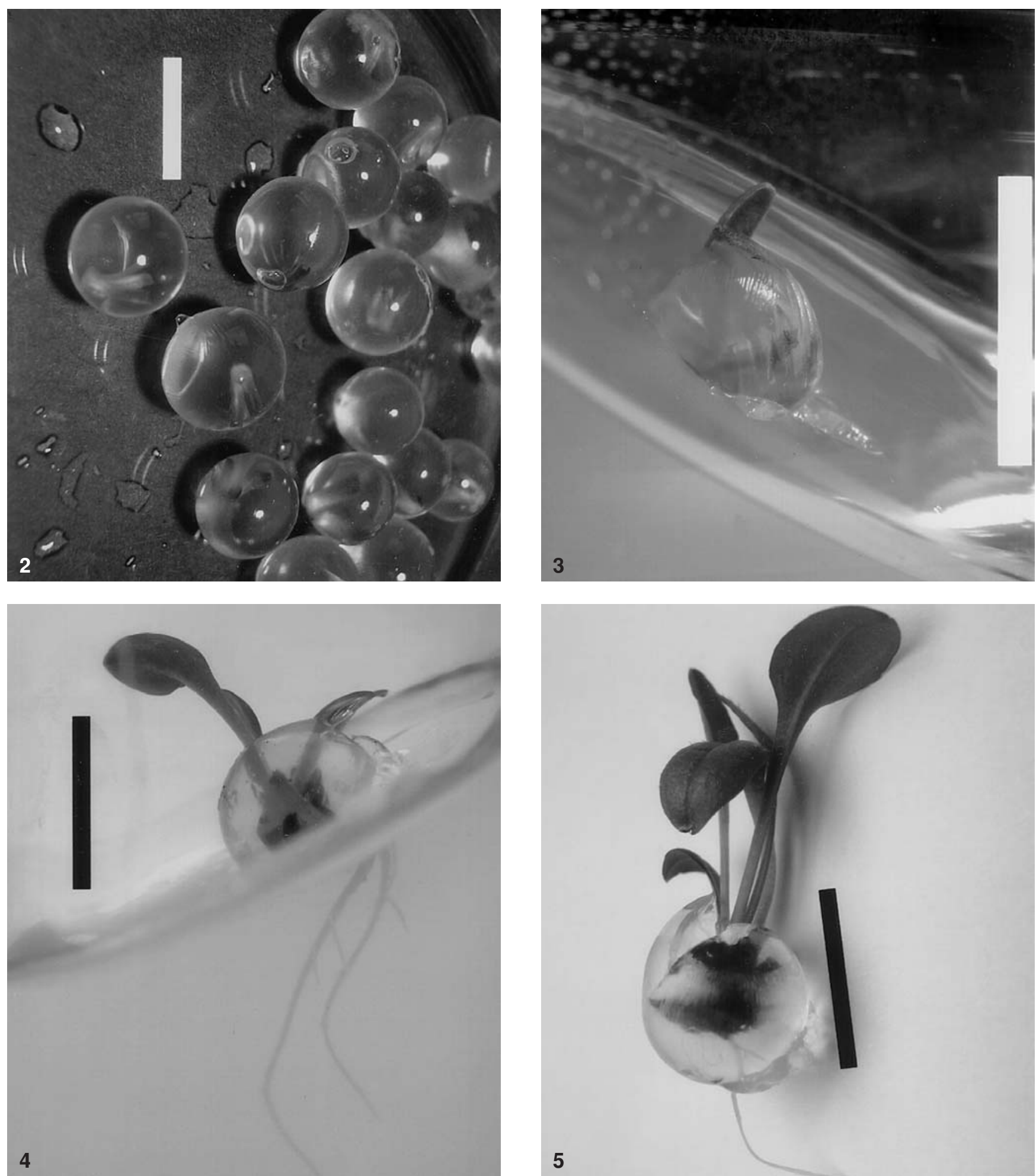

Figs 2-5. Plantago asiatica L. somatic seeds, their germination and conversion into plants. Scale bar 1 cm. Fig. 2 - photo: Mariusz Michalak, Figs 3-5 - photo: Mateusz Pigoń.

Fig. 2. Encapsulated shoot tips in alginate matrix.

Fig. 3. Germination of the somatic seed.

Figs 4, 5. Plantlet development from the somatic seed.

pathi et al. 1992) and Manihot esculenta Crantz (Danso and Ford-Lloyd 2003). We succeeded in encapsulating $P$. asiatica shoot tips isolated from shoot culturing in vitro. The use of apical shoot buds, as well as axial shoot buds (meristems), assures a high degree of genetic stability; counteracting somaclonal variation.
We have found that the capacity to form plants from encapsulated shoot tips of $P$. asiatica depended on the time of preservation in low temperature and the presence of sucrose in the capsule. Other authors have also demonstrated that storage at low temperature significantly reduces the viability and plant recovery frequency of alginate-encapsu- 


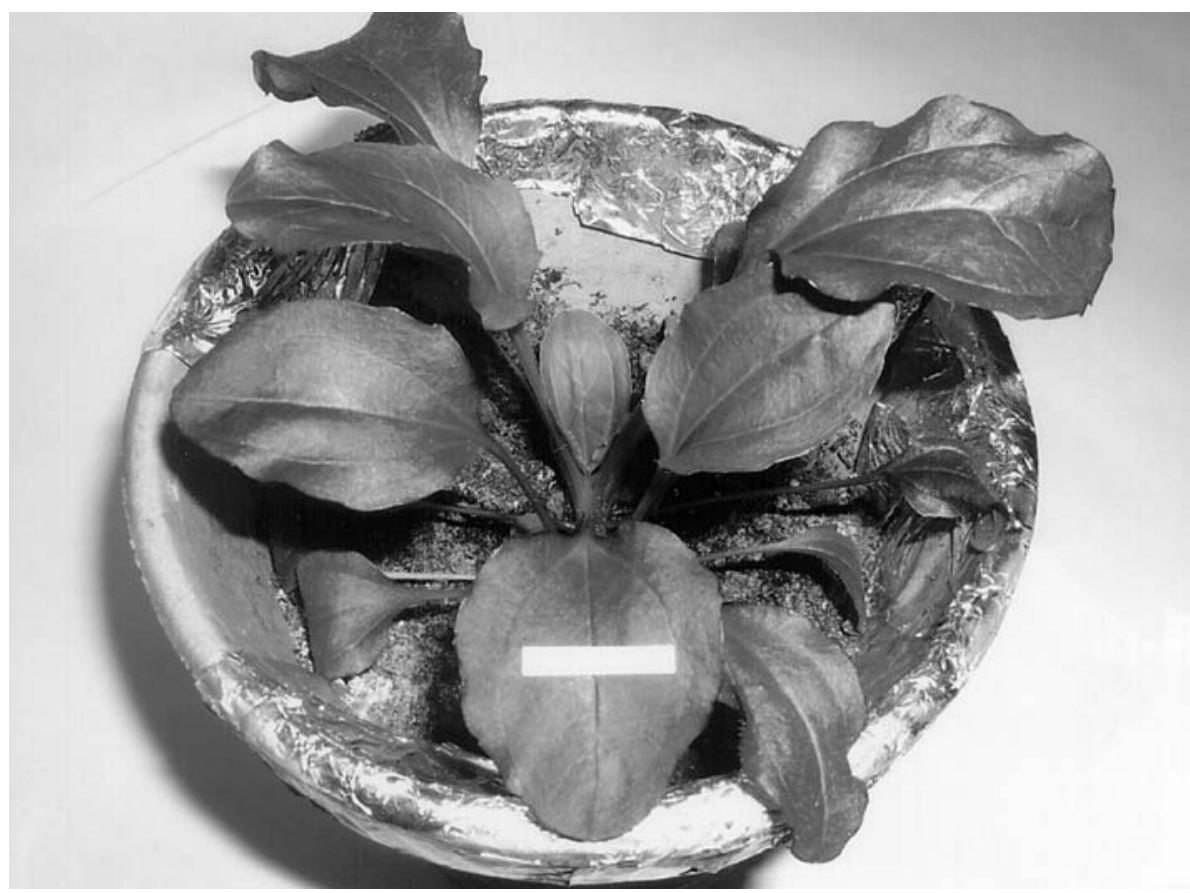

Fig. 6. The plants obtained from somatic seeds in the 2-week soil culture. Scale bar 1 cm. Photo: Mateusz Pigoń. lated embryos and other explants of many plant species, for example: artificial seeds with somatic embryos of Camelia japonica L. (Janeiro et al. 1997), Asparagus cooperi Baker (Gosh and Sen 1994) and Paulownia elongata Sh-y, Hu (Ipekci and Gozukirmizi 2003) or encapsulated shoot buds of Catalpa ovata G. Don (Wysokińska et al. 2002) and Morus indica L. (Bapat et al. 1987), or nodal cuttings and shoot tips of Manihot esculenta Crantz (Danso and FordLloyd 2003). However, encapsulated apical and axial shoot buds of Valeriana wallichii DC. do not lose germinating ability during 6-month storage in refrigerator (Mathur et al. 1989).

$3 \%$ Sucrose presence in capsules very distinctly influences on somatic seeds of $P$. asiatica germination and conversion into plants. Sucrose addition to capsule is often used by authors for artificial seeds of various plants (Janeiro et al. 1997; Mathur et al. 1989; Wysokińska et al. 2002). Danso and Ford-Lloyd (2003) encapsulated shoot tips of Manihot esculenta Crantz supplementing capsules with various concentrations of sucrose. According to these authors the concentration of sucrose in the alginate matrix did not significantly affect shoot development, but it did affect root formation.

Some authors use growth regulators for supplementing capsules, for example Danso and Ford-Lloyd (2003) used them for encapsulated shoot tips and nodal cuttings of $M a$ nihot esculenta. According to these authors the presence of cytokinin (BAP) and auxin - $\alpha$-naphthaleneacetic acid (NAA) in the alginate matrix enhanced early development of shoot from encapsulated nodal cuttings of Manihot esculenta. We have not observed the influence of cytokinin (IBA in concentration $0.1 \mathrm{mg} / \mathrm{dm}^{3}$ ) on the ability to form plantlets and plants of $P$. asiatica.

The results of our study show that $P$. asiatica plants from stored - encapsulated shoot tips, successfully transferred into soil, were well adapted and developed into phenotypically normal plants.

Micropropagation of $P$. asiatica may be conducted through encapsulation of shoot tips.

\section{ACKNOWLEDGEMENTS}

The work is financed by the fund Medical University of Lodz. No. 502-13-328.

\section{LITERATURE CITED}

ANDRZEJEWSKA-GOLEC E. 2005. Babka azjatycka - Plantago asiatica L. - roślina lecznicza Dalekiego Wschodu. Post. Fitoterapii 15: 29-34.

ANDRZEJEWSKA-GOLEC E., MAKOWCZYŃSKA J. 2001. Różnicowanie pędów z tkanki kalusowej Plantago asiatica L. In: Botanika w dobie biologii molekularnej. Materiały sesji i sympozjów 52. Zjazdu PTB. Zenkteler E. (ed.). Poznań, p. 159. (in Polish)

BACH A. 2001.Technologie sztucznych nasion. In: Biotechnologia roślin. Malepszy S. (ed.). PWN, Warszawa, 295-306. (in Polish)

BAPAT V., MHATRE M., RAO P.S. 1987. Propagation of Morus indica L. (Mulberry) by encapsulated shoot buds. Plant Cell Rep. 6: 393-395.

DANSO K.E., FORD-LLOYD B.V. 2003. Encapsulation of nodal cuttings and shoot tips for storage and exchange of cassava germplasm. Plant Cell Rep. 21: 718-725.

GANAPATHI T.R., SUPRASANNA P., BAPAT V.A., RAO P.S. 1992. Propagation of banana through encapsulated shoot tips. Plant Cell Rep. 11: 571-575.

GOSH B., SEN S. 1994. Plant regeneration from alginate encapsulated somatic embryos of Asparagus cooperi Baker. Plant Cell Rep. 13: 381-385.

IPEKCI Z., GOZUKIRMIZI N. 2003. Direct somatic embryogenesis and synthetic seed production from Paulownia elongata. Plant Cell Rep. 22: 16-24.

JANEIRO L.V., BALLESTER A., VIEITEZ A.M. 1997. In vitro response of encapsulated somatic embryos of camellia. Plant Cell Tiss. Org. Cult. 51: 119-125.

MAKOWCZYŃSKA J., ANDRZEJEWSKA-GOLEC E. 2000. Somatic embryogenesis in in vitro culture of Plantago asiatica L. Acta Soc. Bot. Pol. 69: 245-250.

MAKOWCZYŃSKA J, ANDRZEJEWSKA-GOLEC E. 2003. Micropropagation of Plantago asiatica L. through culture of shoot-tips. Acta Soc. Bot. Pol. 72: 191-194. 
MAKOWCZYŃSKA J., ANDRZEJEWSKA-GOLEC E. 2004a. Kapsułkowanie wierzchołkowych części pędów Plantago asiatica L. In: Farmacja - tradycja i nowoczesność. XIX Naukowy Zjazd PTF. Wrocław. Vol. 2, p. 306. (in Polish)

MAKOWCZYŃSKA J., ANDRZEJEWSKA-GOLEC E. 2004b. Kariologiczne badania kalusa Plantago asiatica L. w hodowli in vitro. In: Przyroda polska w europejskim dziedzictwie dóbr natury. 53. Zjazd PTB. Streszczenia referatów i plakatów. Jędrzejczak E. (ed.). Toruń-Bydgoszcz, p. 118. (in Polish)

MAKOWCZYŃSKA J., ANDRZEJEWSKA-GOLEC E., MAREK K. 2005. Cream-coloured and green-coloured lines of the nonmorphogenic callus of Plantago asiatica L. - ultrastructure analysis. Acta Soc. Bot. Pol. 74: 187-192.

MATHUR J., AHUJA P.S., LAL N., MATHUR A.K. 1989. Propagation of Valeriana wallichii DC. using encapsulated apical and axial shoot buds. Plant Sci. 60: 111-116.

PATTNAIK S., CHAND P.K. 2000. Morphogenic response of the alginate-encapsulated axillary buds from in vitro shoot cultures of six mulberries. Plant Cell Tiss. Org. Cult. 60: 177-185.

PAUL H., DAIGNY G., SANGWAN-NORREEL B.S. 2000. Cryopreservation of apple Malus x domestica Borkh. shoot tips following encapsulated-dehydratation or encapsulated-vitrification. Plant Cell Rep. 19: 768-774.

REDENBAUGH K., SLADE D., VISS P., FUJII J.A. 1987. Encapsulation of somatic embryos in synthetic seed coats. Hort. Sci. 22: 803-809.

REDENBAUGH K., FUJII J., SLADE D., VISS P., KOSSLER M. 1991. Artificial seeds - encapsulated somatic embryos. In: Biotechnology in agriculture and forestry. High-tech and micropropagation I. Bajaj Y.P.S. (ed.). Springer-Verlag. Berlin Heidelberg, 17: 395-416.

ROUT G.R., DAS G., SAMANTARAY S., DAS P. 2001. Micropropagation of Plumbago zeylanica L. by encapsulated nodal explants. J. Hort. Sci. Biotech. 76: 24-29.

TU Y. 1996. Tissue culture of Asiatic plantain (Plantago asiatica). Zhongcaoyao 27: 296-298. (in Chinese with English summary)

WYSOKIŃSKA H., LISOWSKA K., FLORYANOWICZ-CZEKALSKA K. 2002. Plantlets from encapsulated shoot buds of Catalpa ovata G. Don. Acta Soc. Bot. Pol. 71: 181-186. 